\section{IJ§ER}

ISSN: 2149-5939
International Journal of Social Sciences and Education Research

Online, http://dergipark.gov.tr/ijsser

Volume: 3(2), 2017

\title{
The research of the level of social media addiction of university students
}

\author{
Mehmet Ali Gazi ${ }^{1} \quad$ Muharrem Çetin ${ }^{2} \quad$ Caner Çakı $^{3}$
}

Received Date: 01 / 09 / $2016 \quad$ Accepted Date: 15 / 01 / 2017

\begin{abstract}
Nowadays, social media has become an indispensable part of our daily lives. Although there are many useful applications of social media, the excessive use of this medium led to live personal, social and occupational problems. With these problems, it began to lead social media addiction which describes as a new kind of addiction. in this regard, the survey will be applied 350 students who study at communication faculty of inonu university through social media selected via simple random sampling online via social media to measure social media addiction. The aim of the study is to identify whether there is a statistically significant differentiation between social media addiction levels of users; according to gender, age and educational situation, daily social media use time and tool used to connect to social media
\end{abstract}

Keywords: Social media, addiction, scale

\section{Introduction}

Twenty-first century is a century that separates itself from previous periods with many characteristics. In this century, also known as the information age, computer and internet have infiltrated all areas of our lives. When people transmit emotions and thoughts to each other started using telegraph before. Then this communication tool left its place to communication tools such as fixed telephones and letters. Nowadays people started using social media to play games and communicate with each other, to shopping and in order to fulfill many functions at the same time.

Excessive use of social media facilitated daily life have emerged various problems. Some users have used social media for a long time in that can neglect activities related to their lives. These users are increasingly faced with more problems and psychological deterioration in their lives due to unhealthy problematic social media usage behavior (Morahan and Schumacher, 2000:16). The reason of this is thought that some individuals have used social media as they need it and some have problems in their work, school and social life depending on their inability to achieve this balance (Odabaşığlu, 2007:41).

These problems are defined as thinking social media continuously, thinking that the time spent outside of social media is meaningless, increasing in current use time continuously, not control-

\footnotetext{
${ }^{1}$ İnönü University, Malatya, TURKEY, mehmetaligazi@hotmail.com

${ }^{2}$ Gazi University, Ankara, TURKEY, cetinm@gazi.edu.tr

${ }^{3}$ İnönü University, Malatya, TURKEY, caner.caki@inonu.edu.tr
} 
Gazi, M.A., Çetin, M., Çakı, C. (2017). The research of the level of social media addiction of university students. International Journal of Social Sciences and Education Research, 3(2), 549-559.

ling social media usage time, a feeling of negative emotion when no access is provided and excessive use which causes the behavior of neglecting in professional family and social life (Arisoy, 2009:25)

Computer and internet usage has been spreading every day in every part of society and age group all around the world and also in Turkey. The Household Information Technologies Research conducted by Turkey Statistics Institute (TURKSTAT) which focused on 16-74 age group in Turkey has determined that the age group in which the rate of computer and internet use is the highest is 16-24 (Turkish Statistical Institute [TSI], 2015). When we look at Turkey statistics; our country has 79.14 million population, we have observed that 46.3 million people of this population have connected to internet. While 42 million of Internet users have actively involved connect to social media, 36 million of these users have accessed social media from mobile devices. $77 \%$ of internet users in Turkey have been online every day, $16 \%$ have connected to the internet at least once a week. $51 \%$ of the web traffic has been carried out on laptops and desktop computers, $46 \%$ mobile devices and $4 \%$ tablets. According to the education level, it has been founded that the most computer and internet users are college, faculty and higher graduates. The use of social media is very prevalent because of its features such as that internet access is easy on university campuses and that students must have a flexible program.

According to these statistics, it has been determined that the first users of social media are formed by young population. That the younger generation is starting to use this new media quickly and their accessibility to new technologies have started to cause problematic usage behaviors beside the benefit they provide. According to these statistics, it has been determined that the first users of social media consist of young population. It has also started to cause problematic usage behaviors besides the benefits provided by that the younger generation has started to use this new media quickly and have their accessibility to new technologies. We have defined this behavior as social media addiction. The addiction can be defined as the ability to stop or control the use of a substance or behavior (Egger \& Rauterberg, 1996).

Whether individuals are addicted to social media isn't arbitrary, it is also not done by observation alone. For this purpose, the validated and proven criteria have been used. In order to determine social media dependency, no scale was found in the field. Instead, the "Internet Addiction Scale" developed by Bayraktar (2001) was adapted as the "Social Media Dependency" scale. In accordance with the purpose of working in this framework, this scale is redesigned by analyzing the validity and reliability by adapting it as a social media addiction scale

In the first part of the study, literature was searched and social media dependency was defined. In the second part, addiction level and usage habits of students to the social media with the expressions regarding addiction and usage habits directed to students in order to measure social media addiction were determined, and the relationship between social media addiction and some variables was also determined.

\section{Review of literature}

Social media is defined as web 2.0-powered databases that provide either individually or institutionally to identify themselves, and provide the substructure for others to comment (O'reilly, 2007:17). It is a web interface that enables social base transformations in terms of interactivity, presented by the modern technologies to the use of the individuals to connect and engage with 
Gazi, M.A., Çetin, M., Çakı, C. (2017). The research of the level of social media addiction of university students. International Journal of Social Sciences and Education Research, 3(2), 549-559.

other social media users particularly. Social media has become a new way of life for people because of the convenience that allows them to communicate at any time. It is stated that the social activity sharing tools such as Facebook and Twitte used by especially the youngsters more intensely have created an internal obstacle in fulfilling their responsibilities by negatively affecting the social, familial relations and health (Esen, 2010).

The most important reason for this is that social media is put on the second plan for a long time, in other words, overuse of the responsibilities. While constant social media thinking, social media anxiety and unhappiness, non-self-control behaviors are defined as social media cognitive disorders; it is possible to define behavioral disorders such as not being able to control the duration of social media usage, refusing to socialize when experiencing a problem, and failing to fulfill responsibilities in social, academic, familial and professional relations (Keser- Özcan and Buzlu, 2007).

Young (1996) has described the fact that the individual is internet addicted in four main factors. It is possible to revise these factors as a social media addiction factor. These factors have been grouped into four categories: Social Support Need, Living Conditions, Sexual Adultness and Creating a New Character.

Social Support Need: It is defined that the social environment which we do not have in real life is created through the creation of various interactive content such as chat groups, games in the social media. It is said that he feels comfortable in communicating because he does not encounter any personal obstacles in expressing his individual feelings, opinions, beliefs and selfexpression thanks to the online environments. It is thought that he/she has preferred virtual life relations instead of real life, by considering to form social relations that he/she cannot have in his daily life.

Living Conditions: It is stated that that the only environment where they can receive social support and socialize of the individuals who do not enter social interaction very much in daily life is the social media environment presented through social media. Therefore, it is stated that these individuals are more likely to exhibit problematic social media usage behaviors.

Sexual Adultness: Social media has allowed individuals to freely live their sexual dictations in sexual channels as well as in many communication channels, allowing them to communicate without giving their true identity. It has been defined as the display of sexual behavior by individuals who do not actually find themselves attractive or who fail in their sexual lives due to these characteristics.

Creating a New Character: As in other types of behaviors, social media is able to change the behavior of individuals with the possibility of secrecy to show themselves differently than they are. In this respect, other forms of characterization are defined at this stage such as feeling as different characters than what they have imagined, or are in their dreams (Peker Demir, 2014).

The developmental periods of young people studying at university are called as Young Adults Term by Erikson (1968). The behaviors that attract attention in the individuals in this period; is defined as distance to intimacy and confusion of identity. The distance to intimacy are defined as the ability to establish close relationships with the same and opposite individuals, and the identity confusion as an attempt to create an own identity. (Erikson, 1968). In other words, the demand 
Gazi, M.A., Çetin, M., Çakı, C. (2017). The research of the level of social media addiction of university students. International Journal of Social Sciences and Education Research, 3(2), 549-559.

for realization theirselves of the undergraduate students in this period, individualization or willingness to live in a unique way have brought about an identity crisis. This identity crisis has created stress on undergraduate students and has led to various problems (Ergin, 1993).

\section{Methodology}

In this study, which considers social media addiction as the matter, questionnaire management was used on the internet which is a computer-based survey management as data collection method. One of the most important advantages of the method is that the data is not needed afterwards because the data is entered directly on the computer, so the data collection and coding process can be performed at the same speed. It removes the problems of incorrect data entry which may occur later on data entry. The prepared questionnaire has been prepared for the application after the necessary controls and regulations have been pre-tested on 63 students. The data were obtained from 350 questionnaires, by removing missing and incorrect from 501 questionnaires. Young (1996) defined the individual as an addict of internet while the individual defined 39 hours or more of the time per week as addiction. In this study, 220 participants who have used social media for 4 hours or more were an analyzed by using statistical package program (SPSS 18.0).

\subsection{Data collection tools}

The "Internet Addiction Scale" developed by Bayraktar (2001) was adapted as a "Social Media Dependency" scale to examine participants' social media addiction. Bayraktar's study used 5 Likert scales to measure 19 items with Internet Addiction Index (SPAI). The reliability of the scale (Cronbach's $\alpha$ ) was .92. In this study, Cronbach's $\alpha$ coefficient was calculated as .90. Participants were asked how often they used the 5 -point Likert scale with 32 articles $(1=$ almost never and 5 $=$ very frequent) to measure social media addiction. With the 6 questions in the second part, it was aimed to determine the frequency of social media usage of the students.

\subsection{Analysis of data and statistical tests}

Appropriate statistical analyzes have been used to reach the objectives set in the study. Factor analysis is a statistical technique aiming to measure by combining a large number of mutually related variables of the same structure or quality with a few factors (Büyüköztürk, 2004: 117). Factor analysis can be categorized into two as exploratory factor analysis and confirmatory factor analysis (Özdamar, 2002: 235). Explanatory factor analyzes were applied on the obtained data. The main purpose of our factor analysis is to reduce the number of variables that exhibit participants' social media dependence and to reveal the relationship between variables, in other words to classify variables in social media addiction.

Pearson's correlation coefficients are used to reveal the relationship of the elements that make up the factors and the power of the relationship. The Pearsons correlation coefficient is indicated by "r" and is between -1 and +1 (Altunışık et al 2001: 175-176). The Independent Samples T-Test is also used to show whether gender is related to social media use and social media dependence. One-way analysis of variance (ANOVA) was used to show that social media dependence differs according to age of participants.

In addition, this study has limitations such as low number of participants, unequal number of male and female participants, and being made among students who are studying at Inonu University Communication Faculty. 
Gazi, M.A., Çetin, M., Çak1, C. (2017). The research of the level of social media addiction of university students. International Journal of Social Sciences and Education Research, 3(2), 549-559.

\section{Results}

The research findings on the students studying at Inonu University Communication Faculty are as follows.

\subsection{Some features of participants}

Some information on the demographics of the participants is as follows:

Table 1. Some Features of Participants

\begin{tabular}{|c|c|c|c|}
\hline \multicolumn{2}{|c|}{} & F & \% \\
\hline \multirow{3}{*}{ Sexuality } & Woman & 105 & 47,73 \\
\cline { 2 - 4 } & Man & 115 & 52,27 \\
\hline \multirow{3}{*}{ Age } & $18-21$ & 175 & 79,54 \\
\cline { 2 - 4 } & $22-25$ & 35 & 15,91 \\
\cline { 2 - 4 } & 26 and more & 10 & 4,55 \\
\hline
\end{tabular}

In terms of gender, $47.73 \%$ of the respondents were female and $52.27 \%$ were male. More than half of the participants constitute the age range of $18-21$ with a rate of $79.54 \% .15,91 \%$ of the survey participants are in the age group of $22-25,4,55 \%$ of the age group of 26 and above.

Table 2. Participants' Internet Usage Features

\begin{tabular}{|c|c|c|c|}
\hline \multirow{4}{*}{ Daily Social Media Usage } & & F & \% \\
\cline { 2 - 4 } & Less than 1 hour & - & - \\
\cline { 2 - 4 } & $1-3$ hours & - & - \\
\cline { 2 - 4 } & Between 4-6 Hours & 105 & 47,73 \\
\hline \multirow{4}{*}{$\begin{array}{c}\text { Social media you spend } \\
\text { most of your time }\end{array}$} & More than 6 hours & 115 & 52,27 \\
\cline { 2 - 4 } & Facebook & 150 & 68,18 \\
\cline { 2 - 4 } & Twitter & 20 & 9,09 \\
\cline { 2 - 4 } & Linked In & 5 & 2,27 \\
\cline { 2 - 4 } & MySpace & 3 & 1,36 \\
\cline { 2 - 4 } & YouTube & 30 & 5,45 \\
\hline $\begin{array}{c}\text { Which is the most used so- } \\
\text { cial media from you to } \\
\text { connect to social media? }\end{array}$ & Instagram & 35 & 13,63 \\
\cline { 2 - 4 } & Laptop & 12 & 15,91 \\
\cline { 2 - 4 } & Desktop computer & 28 & 12,73 \\
\cline { 2 - 4 } & Tablet computer & 145 & 65,91 \\
\hline
\end{tabular}

$52,27 \%$ of the respondents used internet more than 6 hours when they examined the internet usage period. Young (1996) said that the group they defined as internet addicts stayed on the Internet for 39 hours per week on average. Facebook is the social media tool where more than $60 \%$ of social media users spend their time. It is seen that Facebook is the most used social media in the world and social media tool which we use most in our sample is Facebook. It is seen that $65,91 \%$ of the vehicles they use to connect to social media are mobile phones. It can be said that the use of social media has increased with the increase of third generation mobile phones called smart phones. The use of the mobile phone can be indicated by the availability of free internet facilities provided by the universities.

\subsection{Social media addiction factor analysis}

Factor analysis was applied in response to the responses given to 32 items in the 5-point Likerttype scale ( 1 - always, 5 - never) prepared to determine social media dependence. The reliability coefficient of the items included in the factor analysis (Cronbach's $\alpha$ ) was found to be .90. Factor 
Gazi, M.A., Çetin, M., Çakı, C. (2017). The research of the level of social media addiction of university students. International Journal of Social Sciences and Education Research, 3(2), 549-559.

analysis was based on the Varimax rotation table and the minimum loading level of 0.50 was used. In the analysis, 3 items were excluded from the study because they did not carry the value of the load or the size of the minimum load was far below. Factors assigned to the factors, factor loadings, arithmetic mean and standard deviations are shown in detail in Table 3.

Table 3. Factor Analysis for Determining Participants' Social Media Addiction

(Principal Component Analysis, Varimax Rotation)

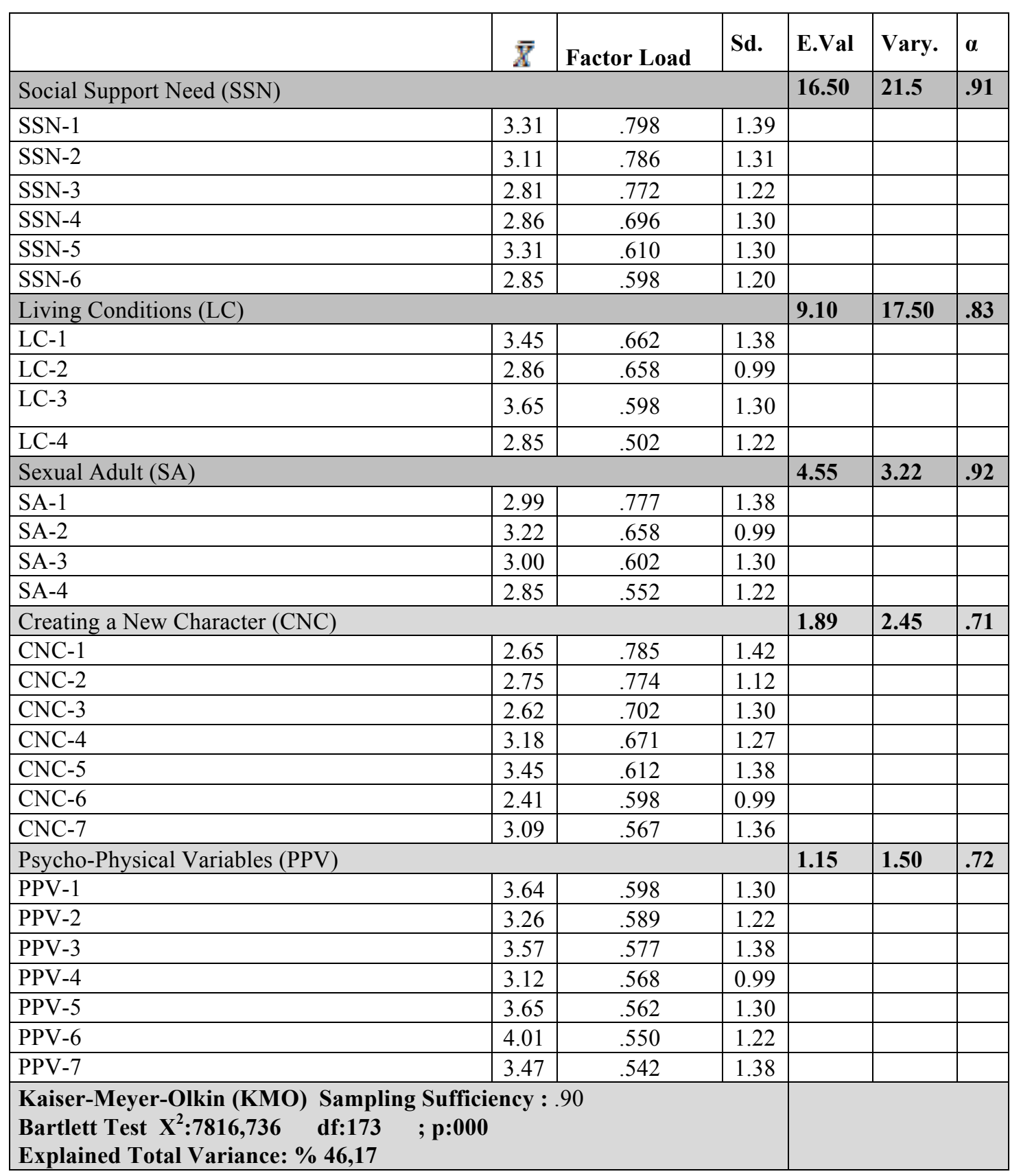

Barlett test and Kaiser-Meyer-Olkin (KMO) test were used to evaluate the results. According to the Barlett test, significant differences were found between the judges subjected to factor analysis and the main group $(\mathrm{p}=.000)$. The KMO value is calculated as .90 . Findings from these studies are evaluated as evidence that the scale can provide valid and reliable measures of social 
Gazi, M.A., Çetin, M., Çakı, C. (2017). The research of the level of social media addiction of university students. International Journal of Social Sciences and Education Research, 3(2), 549-559.

media dependency levels of individuals. These five factors, which emerged as a result of factor analysis on social media dependence, account for $46.17 \%$ of the total variance.

Social support is the most important factor in the social media addiction of respondents. This result also points out that the most effective motivation for students to use social media is Social Support Need. As a result of the analysis, 6 items describing the first factor and having loads above 0.50 were identified. The substances listed under this factor have high standard deviation values. The reliability of the social support needs factor (Cronbach's $\alpha=.91$ ) and eigen value (16.50) are quite satisfactory. The first factor alone accounts for $21.50 \%$ of the total variance.

The second factor, called "Life Conditions," brings together social media items that demonstrate social media addiction on the use of living conditions. The arithmetic mean of the items listed under living conditions ranged from 3.65 to 2.85 and the standard deviations ranged from 0.99 to 1.38 . Cronbach's $\alpha=.83$ and eigenvalue 9.10 as the reliability value account for $17.50 \%$ of the total variance.

The third factor obtained as a result of the analysis is the "sexual accessibility" factor. Sources of sexual arousal; "Relationships established in social media are more romantic", "Relationships that I have established in social media make me happy", "I prefer relations with social media through face-to-face", " . The arithmetic mean of the items in this factor is 2.85 to 3.22; Standard deviations range from 0.99 to 1.42 . The reliability factor of the sexual adulthood factor which explained $3.22 \%$ of the total variance was Cronbach's $\alpha=.92$ and eigenvalue 4.55 .

The fourth factor that results from factor analysis is "New Character Creation". The arithmetic mean of the items in this factor is 2.41 to 3.45 ; Standard deviations range from 0.99 to 1.42 . The new characterization factor introduced by the 7 items with a minimum of .567 and a maximum of .785 in terms of loading rates accounts for $2.45 \%$ of the total variance. The reliability coefficient of the said factor is Cronbach's $\alpha=.71$ and eigenvalue is 1.89 .

The last factor in factor analysis is the "psycho-physical variables" resulting from the use of social media. The arithmetic mean of the items in this factor is 2.01 to 2.99; Standard deviations range from 0.99 to 1.38 . The new characterization factor introduced by the 8 items with a minimum of 536 and a maximum of 598 in terms of loading rates accounts for $1.50 \%$ of the total variance. The reliability coefficient of the said factor is Cronbach's $\alpha=.72$ and eigenvalue is 1.15 .

\subsection{Correlation analysis between social media addiction factors (Pearson r)}

Table 4 shows the results of the correlation analysis in order to describe the level of the relationship between the social media addiction factors of university students participating in the survey in this part of the study.

Tablo-4 Correlation Analysis

\begin{tabular}{|l|l|c|c|c|c|}
\hline & $\begin{array}{l}\text { Social } \\
\text { Support } \\
\text { Need }\end{array}$ & $\begin{array}{l}\text { Living } \\
\text { Conditions }\end{array}$ & $\begin{array}{l}\text { Sexual } \\
\text { Adults }\end{array}$ & $\begin{array}{l}\text { Creating a } \\
\text { New Char- } \\
\text { acter }\end{array}$ & $\begin{array}{l}\text { Psycho- } \\
\text { Physical } \\
\text { Variables }\end{array}$ \\
\hline Social Support Need & 1 & & & & \\
\hline Living Conditions &, $645(* *)$ & 1 & & & \\
\hline Sexual Adults &, $399(* *)$ &, $299(* *)$ & 1 & & \\
\hline Creating a New Character &, $844(* *)$ &, 087 &, $302(* *)$ & 1 & \\
\hline PsychoPhysical Variables &, $354(*)$ &, $375(* *)$ &, $288(* *)$ &, $364(* *)$ & 1 \\
\hline
\end{tabular}

** Correlation is significant at the 0.01 level (2-tailed)

* Correlation is significant at the 0.05 level (2-tailed) 
Gazi, M.A., Çetin, M., Çakı, C. (2017). The research of the level of social media addiction of university students. International Journal of Social Sciences and Education Research, 3(2), 549-559.

When looking at the results of the correlation analysis in terms of describing the severity of the relationship between the factors, a strong relationship in the positive direction is needed for a New Character Creation and Social Support Need $(r=.844, \mathrm{p}<.01)$; . Participants are young, and in character they are unable to fully identify themselves, or to express themselves in real life, social support, virtual life, seeking social support through unreal identities. Likewise, there is a strong positive relationship between participants' Social Support Needs and Living Conditions. As the living conditions of the participants deteriorate, social media addiction increases $(r=.64$, $\mathrm{p}<.01)$.

\subsection{Social media dependence and differences between some variables}

Independent sample t-test was used to analyze the participants' social media addiction factors to see whether they differ significantly in gender.

Table-5 The Difference Between Participants' Gender and Social Media Addiction

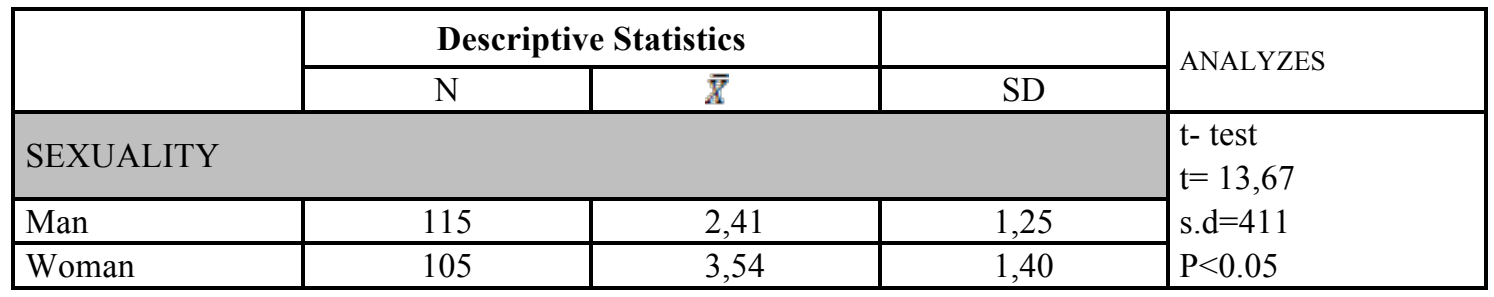

According to the results of the independent sample $t$ test conducted to determine the difference between the gender of students participating in the survey and the social media addiction, there is a significant difference between gender and social media addiction $(t=13,67, \mathrm{~s} . \mathrm{d}=411, \mathrm{p}<0.05)$. When we examine the differences among sex groups, the arithmetic mean value of male students is 2,41 and the arithmetic average value of female students is 3,54 . . Therefore, it is seen that female students are more dependent on social media addiction than male students.

Table-6 The Difference Between Attendees' Ages and Social Media Addiction

\begin{tabular}{|c|l|l|l|l|}
\hline \multirow{2}{*}{} & \multicolumn{2}{|c|}{ Descriptive Statistics } & & \multirow{2}{*}{ ANALYZES } \\
\cline { 2 - 4 } & $\mathrm{N}$ & $\overline{\mathrm{X}}$ & $\mathrm{SD}$ & \\
\hline AGE & 175 & 2,29 & 0,81 & ANOVA \\
\hline $18-21$ & $\mathrm{~F}=5,17$ \\
& $\mathrm{~S} . \mathrm{D}=3$ \\
\hline $22-25$ & 35 & 2,16 & 0,69 & $\mathrm{P}>0,05$ \\
\hline 26 and more & 10 & 2,32 & 0,65 & \\
\hline
\end{tabular}

One-way analysis of variance (ANOVA) was conducted to demonstrate the difference between participants' age and social media dependence. Table-5 shows the results. As a result of the one-way analysis of variance, there was no significant difference between participants' age and social media dependence.

Table-7 The difference between social media usage times and social media addiction of participants

\begin{tabular}{|c|c|c|c|c|}
\hline & \multicolumn{2}{|c|}{ Descriptive Statistics } & & \multirow[t]{2}{*}{ ANALYZES } \\
\hline & $\mathrm{N}$ & $\bar{X}$ & SD & \\
\hline \multicolumn{5}{|l|}{ USE TIME } \\
\hline 4-6 Hours & 105 & 2,62 & 0,81 & \multirow{2}{*}{$\begin{array}{l}\text { ANOVA } \\
F=4.22 \\
\text { s.d }=3 \\
P<0.05\end{array}$} \\
\hline More than 6 Hours & 115 & 3,01 & 0,78 & \\
\hline
\end{tabular}

Copyright (C) 2015 by IJSSER

ISSN: 2149-5939 
Gazi, M.A., Çetin, M., Çakı, C. (2017). The research of the level of social media addiction of university students. International Journal of Social Sciences and Education Research, 3(2), 549-559.

When we examine the difference between participants' use time of social media and social media addiction, there is a meaningful difference in social media use time and social media dependency of students $(\mathrm{F}=4.22$, s.d $=3, \mathrm{P}<0.05)$. As a result of the Tukey test, it was found that the source of significant differentiation at the level of 5\% significance was between those who use social 4-6 hours $\left(\mathrm{X}^{-}=2.62\right)$ and those who use more than 6 hours $\left(\mathrm{X}^{-}=3,01\right)$. At this point, social media usage times increase dependency addiction.

Table- 8 . The difference between used nets and social media addiction

\begin{tabular}{|c|c|c|c|c|}
\hline & \multicolumn{2}{|c|}{ Descriptive Statistics } & & \multirow{2}{*}{ ANALYZES } \\
\hline & $\mathrm{N}$ & $\overline{\bar{X}}$ & SD & \\
\hline \multicolumn{4}{|c|}{ USED NETWORKS } & \multirow{7}{*}{$\begin{array}{l}\text { ANOVA } \\
F=3,91 \\
\text { s.d }=4 \\
\mathrm{P}<0.05\end{array}$} \\
\hline Facebook & 150 & 2,85 & 0,79 & \\
\hline Twitter & 20 & 2,52 & 0,65 & \\
\hline LinkedIn & 5 & 2,31 & 0,72 & \\
\hline MySpace & 3 & 2,1 & 0,48 & \\
\hline YouTube & 12 & 1,99 & 0,69 & \\
\hline İnstagram & 30 & 2,39 & 0,67 & \\
\hline
\end{tabular}

When the difference between the social media networks and the social media dependence of the students participating in the research was analyzed, it was found that there was a significant difference between the affiliated social networks and social media addiction $(F=3.91, s . d=4, p$ $<0.05)$. However, when we examine the direction of this differentiation, it is seen that the difference is only between Facebook users and YouTube users. Students who use YouTube on the social media have an average of $\mathrm{X}^{-}=1.99$ and those who use an average Facebook have an average of $\mathrm{X}^{-}=2.85$. According to these data, students who use Facebook are more social media addicts than those who use YouTube (mean difference $=0.86)($ Table-8). However, apart from this difference, it has been achieved that there is no difference between those who use other social networks (LinkedIn, Twitter, MySpace, Instagram) and social media addiction.

Table-9 Difference between vehicle and social media dependence used by participants

\begin{tabular}{|c|c|c|c|c|}
\hline & \multicolumn{2}{|c|}{ Descriptive Statistics } & \multirow[b]{2}{*}{ SD } & \multirow{2}{*}{ ANALYZES } \\
\hline & $\mathrm{N}$ & $\bar{X}$ & & \\
\hline \multicolumn{4}{|l|}{ USED TOOLS } & \multirow{5}{*}{$\begin{array}{l}\text { ANOVA } \\
F=4,1 \\
\text { s.d }=4 \\
P<0.05\end{array}$} \\
\hline Laptop & 35 & 2,11 & 0,81 & \\
\hline Deskop Computer & 12 & 1,99 & 0,72 & \\
\hline Tablet Computer & 28 & 2,23 & 0,76 & \\
\hline Mobile Phone & 145 & 2,99 & 0,82 & \\
\hline
\end{tabular}

When we examine the difference between the means used by the participants to connect to social media and the social media addiction, it is seen that there is a meaningful difference between the tool used and social media addiction $(F=4,1, \mathrm{~s} . \mathrm{d}=4, \mathrm{p}<0.05)$. In the Tukey test, which is aimed to show the difference between the different groups, it is seen that the vehicle connected to social media is between the desktop computer $\left(X^{-}=1.99\right)$ and the mobile phone $\left(X^{-}=2.99\right)$. It can be said that participants who are connected to social media are more dependent on those who are connected with the desktop computer.

\section{Conclusion}

Social media addiction, which can be counted as a new addiction in literature, is considered as a problem that both psychologists and clinicians are emphasizing. The Internet addiction, which 
Gazi, M.A., Çetin, M., Çakı, C. (2017). The research of the level of social media addiction of university students. International Journal of Social Sciences and Education Research, 3(2), 549-559.

is especially affecting the adolescent individuals, can bring psychological, sociological and physiological problems on the individual (Karaca, 2007: 12). As the diagnosis of whether or not individuals are internet addicts can not be random, this diagnosis can not be done by observation alone. An assessment can only be made on the time users spend on social media. Yang and Tung (2004) report 21 and Eijnden (2008) and his colleagues report 35 hours, indicate a person as an internet addicted that they are connected to the Internet for 39 hours per week on average. This implies that the criteria used in the definition of addiction are different and accordingly the method used in the research, which results from the selected measurement tools, is also effective. In this study, young people who have used social media for 39 hours or more per week were analyzed.

As a result of this study, a social media addiction scale consisting of 29 items was developed. This study was conducted over 220 students; The internal consistency coefficient of Cronbach alpha (a) was .90. Explicit factor analysis was applied to the scale and the appropriateness of the sample size was confirmed by KMO and Barlett statistic $(\mathrm{KMO}=.90, \mathrm{c} 2=7816,73, \mathrm{p} @ 0.000)$. As a result of exploratory factor analysis, 5 sub-factors related to the scale were reached. These 5 sub-factors; "Social Support Need", "Living Conditions", "Sexual Adultity", "Creating a New Character", Psycho-physical Variables ", the total declared variance for the scale was 46,17\%.

Findings reached as a result of the study; Of the students who participated in the survey, $47.73 \%$ were female and $52.27 \%$ were male. More than half of the participants (79.54\%) constitute the 18-21 age range. It is seen that female students are more dependent on social media addiction than male students. The difference between social media use time and social media dependence is found to be between 4-6 hours users $\left(\mathrm{X}^{-}=2.62\right)$ and users who use more than 6 hours $\left(\mathrm{X}^{-}=3,01\right)$. At this point, it can be said that social media usage times increase redundancy addiction. It has been found that there is a meaningful difference between participants' social networks and social media dependence. However, when we examine the direction of this differentiation, it is seen that the difference is only between facebook users and YouTube users. Students who use YouTube on the social media have an average of $\mathrm{X}^{-}=1.99$ and those who use an average Facebook have an average of $X^{-}=2.85$. According to these data, the students who use Facebook by way of going out are found to have more social media dependencies than those who use YouTube (average difference $=0.86$ ). The tools that students use to connect to social media affect the level of dependence. It seems to be between the desktop computer $\left(\mathrm{X}^{-}=1.99\right)$ and the mobile phone $\left(\mathrm{X}^{-}=2.99\right)$. It can be said that participants who are connected to social media are more dependent on those who are connected with the desktop computer.

As a result, the important restrictions are that the sample of the research does not represent the entire universe and constitutes the students of İnönü University Faculty of Communication. Realization of similar studies on different and wider samples will allow generalization from research results. Such studies will contribute to the diversity and enrichment of the literature in Turkey.

\section{References}

Altunışık, R., Coşkun, R., Bayraktaroğlu, S., \& Yıldırım, E. (2010). Sosyal bilimlerde araştırma yöntemleri: SPSS uygulamalı. Sakarya yayınc1lık.

Arisoy, Ö. (2009). İnternet bağımlılı̆̆ı. Turkiye Klinikleri Journal of Psychiatry Special Topics, 2(1), 7583.

Bayraktar, F. (2001). Internet kullanımının ergen gelişimdeki rolü (Doctoral dissertation, Ege Üniversitesi). 
Gazi, M.A., Çetin, M., Çak1, C. (2017). The research of the level of social media addiction of university students. International Journal of Social Sciences and Education Research, 3(2), 549-559.

Büyüköztürk, Ş. (2009). Sosyal bilimler için veri analizi el kitabı: İstatistik, araştırma deseni, SPSS uygulamalar1 ve yorum (9. bask1). Ankara: Pegem Yayınlar

Egger, O., \& Rauterberg, M. (1996). Internet behaviour and addiction. Semester thesis (Swiss Federal Institute of Technology, Zurich, 1996).

Eijnden RJJM, Meerkerk GJ, Vermulst AA, Spijkerman R, Engels CME. Online communication, compulsive internet use, and psychosocial well-being among adolescents: A longitudinal study. Dev Psychol 2008; 44:655-665.

Ergin, N. (1993). İntihar girişimi olan ve olmayan lise öğrencilerin kendini kabul ve depresyon düzeylerinin karşılaştırılması, Yayınlanmamış Doktora Tezi, Ankara Üniversitesi, Ankara

Erikson, E. (1968). Childhood and society. New York: Norton Press

Esen, E. (2010). Ergenlerde internet bağımlılı̆̆ını yordayan psiko-sosyal değişkenlerin incelenmesi (Doctoral dissertation, DEÜ Eğitim Bilimleri Enstitüsü).

Karaca, M. (2007). Sosyolojik bir olgu olarak internet gençliği: Elazı̆̆ örneği. Yayınlanmamış doktora tezi, Fırat Üniversitesi, Sosyal Bilimler Enstitüsü, Sosyoloji Anabilim Dalı, Elazı ̆̆

Keser Özcan, N. ve Buzlu, S. (2005). Problemli internet kullanımını belirlemede yardımcı bir araç: “internette bilişsel durum ölçeği”nin üniversite öğrencilerinde geçerlik ve güvenirliği. Bağımlılık Dergisi, 6(1), 19-26. [Çevrim-içi: http://www.bagimlilikdergisi.com/pubfiles/cilt6sayi1003.pdf], Erişim tarihi: 10 Nisan 2011.

Morahan---Martin J, Schumacher P (2000).Incidence and correlates of pathological internet Use among college students.Computers in Human Behavior, 16(1), 13---29.

Odabaşığlu, G., Öztürk, Ö., Genç, Y., \& Pektaş, Ö. (2007). On olguluk bir seri ile internet bağımlılı̆̆1 klinik görünümleri. Bă̆ımlılık Dergisi, 8(1), 46-51.

O'reilly, T. (2007). What is Web 2.0: Design patterns and business models for the next generation of software. Communications \& strategies, (1), 17.

Özdamar, K. (2002). Statistical Data Analysis with Package Programs: II (Multivariate Analysis)(in Turkish), Kaan Kitabevi, 4. Bası, Eskişehir, 235-276.

Peker Demir, E. (2014). İnternet Aracılı ile Kişilik Haklarına Saldırı. Yüksek Lisans Tezi. İstanbul Kültür Üniversitesi, Sosyal Bilimler Enstitüsü, İstanbul.

Yang SC, Tung C. Comparison of internet addicts and non-addicts in Taiwanese high school. Computers in Human Behavior 2004; 23:79-96.

Young KS. Internet addiction: The emergence of a new clinical disorder. Cyberpsychol Behav 1998; 1:237244.

www.tuik.gov.tr 